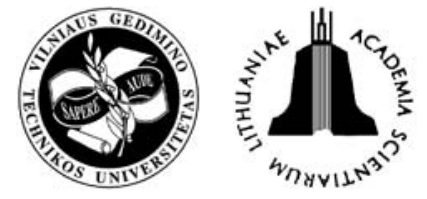

TRANSPORT

2008

23(1): $88-90$

EXCHANGE OF EXPERIENCE

\title{
CHOSEN ASPECTS OF MUNICIPAL TRANSPORT OPERATION ON THE EXAMPLE OF THE CITY OF LUBLIN
}

\author{
Andrzej Niewczas, Grzegorz Koszalka, Jan Wrona, Daniel Pieniak \\ Lublin University of Technology, Dept of Internal Combustion Engines and Transport, \\ 36 Nadbystrzycka, 20-618 Lublin, Poland. E-mail: a.niewczas@pollub.pl
}

Received 14 April 2007; accepted 20 November 2007

\begin{abstract}
The paper presents some aspects of operation of municipal transport system in the city of Lublin (Poland). Organization of Lublin Municipal Transport Company was described, its efficiency and perspectives of development. Particular attention was paid to the rules of adjustment to the EU requirements, and to the influence of demographic and social factors. Infrastructure of public transport in Lublin was analyzed (busses, trolley-busses, bus stations, fixed objects and bus stops), as well as configuration of bus and trolley-bus lines. Some specific proposals were also put forward regarding development solutions: development plan of trolley-bus traction, plan of inter-connection bus station, development plan of bus traction, introduction of advanced IT solutions into the public transport management and natural gas (CNG) fuelling of the city busses.
\end{abstract}

Keywords: urban transport, urban transport problems.

\section{Introduction}

Lublin is a city with a very rich past, to which it owes its distinctiveness and identity, and also specific for its localization development conditions. Taking advantage of these features in the plans of the municipal transport operation should be a base of strategic program of sustainable city development.

The most important factors in the development of passenger transport in Lublin are: construction of expressways, improvement of railway connections and building of an airfield which will serve as a Lublin's gate to the open world. It is also necessary to expand and improve existing transport infrastructure, especially related to the trolley-bus network.

Architectural structure and building development in the city centre is beneficial for the further development of the road communication. In this respect advantageous influence is made by numerous river-beds and ravines, which prevent compact settlement. Some problems are related to the arrangement and scale of huge housing estates and irregular layout of clusters of places of employment. In consequence, a significant deficiency of places of employment can be observed in the vicinity of residential zones and gaps in the development of the inner municipal transport services.

In the scope of organization and management of municipal transport, three models can be distinguished by Rydzykowski, Wojewódska-Król (2002): transport without any public regulation, transport subject to public control and realized by one monopolistic company, transport under public control and realized by competitive transport companies.

System of municipal transport existing in Lublin so far does not meet any of the above models. Its functioning is based on the public regulation, but is not put into practice in a uniform manner for all common carriers. There are two main common public transport companies in Lublin: Municipal Transport Company (MPK) and City Bus Service (AKL). MPK Ltd. is a municipal company and renders its services for the citizens of Lublin with consideration to the public transport duties, social politics and other factors, which the city has to fulfill in relation to its inhabitants. AKL is a consortium associating dozens of private carriers which offer transport services characterized by uniform transport tariff with no regard to the social and public politics of the city. 


\section{Municipal transport system}

Lublin has traffic configuration typical for Polish cities, i.e. ring-shaped and radial, that is presented by Wrzolek (2004). This configuration is a result of natural evolution. With the growth of the city around its centre, where main institutions were located, traffic configuration evolved from typically concentric to radial. Main routes leading to the centre appeared. Particular quarters started to gain individual character. Some of the quarters, as in other cities, became typically industrial on the area where only industrial plants were grouped, e.g. in Lublin: Majdan Tatarski, Zadebie, Wrotkow, Bursaki. These quarters are located on the north, east and south peripheries. In other regions of Lublin (opposite) residential quarters were built, so called "bedrooms", like LSM, Czuby, Konstantynow, that is presented by Wrzolek (2004).

In practice the whole traffic from these residential quarters to the places of employment goes through the downtown. It was necessary to build arterial roads, which would allow to by-pass downtown. In consequence Lublin obtained the most typical configuration of traffic network, i.e. ring-shaped and radial. Radial directions are used mostly for the communication between the city centre and the quarter served. Ring roads provide variety of services and allow for reduction of number of radii coming from downtown. Ring roads also serve the purpose of through roads relieving the centre from unbounded traffic, that is presented by Wrzolek (2004), Wyszomirski and Gromadzki (2004).

System of public transport in Lublin consists of two subsystems, by MPK Liublin (2005): bus network and trolley-bus network. These subsystems are integrated and organized and put into practice by MPK Lublin Ltd.

MPK Lublin has 209 busses. Most of them are 8-10 years old and more. According to the state on $31 \mathrm{Dec}$. 2005, MPK and AKL realized public transport services on the following areas: city of Lublin - 61 lines, Jastkow commune - 2 lines, Konopnica commune - 2 lines, Niemce commune - 1 line, Niedrzwica Duza commune - 1 line, Glusk commune - 2 lines, Wolka Lubelska commune -1 line. Except the above mentioned bus lines there are also seven free bus lines serving huge shopping centers and one school-bus line (Gim).

MPK in Lublin has also 63 trolley-busses. Most of them are more than 10 years old. Every day 39 trolleybusses leave for the streets, serving 8 lines.

Apart from the above mentioned factors, functioning of the municipal transport is formed by many conditions which are independent from the transport companies and city authorities. Some of them are: number of inhabitants (approx. 355 thousand), number of persons in productive age (approx. $65 \%$ of all inhabitants), unemployment rate (12\%), employment level in different branches, arrangement of biggest working places, age structure (approx. $66 \%$ between 18 and 59), number of registered passenger cars, number of unemployed.

\section{Problems of public transport services in Lublin and solution examples}

The most important problems of public transport in Lublin are: lack of proper transport infrastructure, low quality of service provided by transport companies operating in Lublin, lack of uniform management system, low level of financial subventions assigned to transport in comparison to its costs, low frequency of connections and insufficient diversification of means of transport.

Establishing the main reasons of bad functioning of transport is a key issue for further discussion about improvement of municipal transport services in Lublin. Low transport quality and low frequency of connections are related to the shortage of proper road infrastructure. Such situation forces transport companies to establish lines going through downtown. This is also related to the other negative factor, which is superimposing of line directions, what in turn generates huge costs. Another source of faults in municipal transport services in Lublin is lack of proper body managing and organizing public transport. All the tasks related to the management are implemented by suitable units of MPK Ltd. It generates additional costs for this company. Low quality of transport is also caused by the lack of fixed rules regarding choice of vehicle makes and their types. There are no decrees establishing vehicle age, after which it should be taken out of service.

Next group of problems is related to the funds assigned by the city for the functioning of public transport. All the subventions are given to MPK Lublin. These funds are used to cover losses coming from transport on the unprofitable lines and from transport allowances (pensioners, children, unemployed, schoolchildren). According to the data given by MPK and assessments of independent experts, the total cost of reduced transport fares given by MPK only, amounted to approx. $27 \mathrm{mln}$ zloty, whereas subvention from the city authorities was only $6.2 \mathrm{mln}$ zloty.

Summarizing, some conclusions can be put forward. Transport company MPK Lublin Ltd. operates as a budgetary firm. For the sake of social character of its activities, it can not compete financially to the full with AKL. Moreover, there are some additional factors, which do not allow for balanced competition: different rules of taxation of both carriers, necessity of administrative service by MPK comprising the whole municipal transport in Lublin. That is why, despite subventions which MPK obtains from the city budget, this carrier encounters financial difficulties. AKL is a commercial enterprise operating as a consortium of many small providers of transport services, and is exclusively oriented towards current financial profit. Therefore quality of services is of less importance.

Indispensable condition of improvement of this situation is introduction of changes in the organization and structure of transport, as well as improvement of financing rules.

The most important task, which should be carried out is isolation of regulatory body from the structures of the transport company, who will manage municipal trans- 
port as a whole. It is of great importance, as managing body implements politics of city authorities responsible for satisfying transport needs of the citizens. Therefore it can not depend on internal conditions of any transport company. Decision-maker in this model is a part of "control zone”. By Rydzykowski, Wojewódzka-Króll (2002) the tasks include: fixing ticket prices, fixing subvention levels, determining scope of services and directions of transport development. In the "control zone" some other tasks should be performed: conducting market research of transport services, planning of transport routes, location of bus-stops and traffic junctions, preparation of time-tables and tariff-ticket solutions, ticket sale and ticket control, estimation of required subvention levels, inviting bids and making contracts with transport companies, supervision, dispatch and control of traffic realization, examination of profitability of transport lines, maintenance of bus-stops, piloting of infrastructural investments, and last but not least, marketing and information.

Another important task to be realized in Lublin is the development of the trolley-bus transport, and not only for the ecological reasons, but also because of the possibilities of improving image of the city. Lublin has undertaken a perennial development program of the trolley-bus network up to 2013. Main stages of this program are: modernization and redevelopment of existing network and supply sub-stations, extension of communication routes on the basis of power reserves of existing sub-stations, new routes of the trolley-bus lines with building of new stations, see MPK Liublin (2004). During the whole period of modernization and expansion of the electric traction, purchase of 60 new trolley-busses is also planned.

New, total system of municipal transport should fulfill the so called "short lines requirement". It will increase transport mobility of the city, create possibility of including new lines and give opportunity to increase vehicle service frequency. Such system can come into being only if certain investments will be undertaken, such as: building of new transfer station in the city centre, establishing bus lines connecting different quarters and residential areas with this station, establishing circumferential bus lines running in the direction of residential area - industrial area (with downtown omission), giving priority to the mass transport in the city centre. Securing full mobility of the transfer station will be possible by linking it to the trolley-bus network, which will be directed towards city centre and peripheral residential areas. This problem is presented by Szadkowski (2000).

So as to improve the image of municipal transport services in Lublin it is substantial to introduce new, ecological propulsion systems. Such solution is fuelling bus engines with compressed natural gas (CNG). Disadvantages of CNG fuelling in the bus transport are high costs of building and maintenance of CNG refuelling stations, including costs of gas compression. The biggest advantage of CNG is its low price - which is of high importance for the company with low profitability what MPK nowadays is.

There are some examples of successful introduction of CNG in municipal transport services in Poland. Since 2003 CNG-fuelled busses have been used by MPK Rzeszow, where a refuelling station has been built. Lately MPK Lublin has acquired a CNG-fuelled bus Solaris Urbino 18. Another solution of ecological bus for the municipal transport is hybrid propulsion. It would have a significant meaning for Lublin - the city, where many lines meet in the downtown; an interesting example of such a bus can be Solaris Urbino 18 Hybrid.

\section{Conclusions}

Good system of municipal transport services is an indispensable condition of general development of Lublin. Actual state of public communication in the city is unsatisfactory. It can be clearly seen, that quality of transport services provided by MPK and private carriers associated with AKL is constantly decreasing.

The authors think, that parallel development of bus and trolley-bus transport is necessary. In central city districts a priority should be to introduce trolley-buss communication. It will significantly reduce the level of toxic exhaust emissions in the centre of the city. It seems also necessary to introduce "rush-hour", quick bus lines along the main traffic routes of the city.

It is also necessary to modernize fleet of busses, especially taking into account modern propulsion systems (CNG-fuelled engines or hybrid drives).

To make all these changes in the municipal transport services possible, it is necessary to create a separate body: managing board of municipal transport. This body should overtake the task of organizing of public passenger transport within the city and adjacent communes. Moreover, this body should deal with unification of ticket fee system and in the future - with complex system of "city card".

\section{References}

MPK Lublin. 2004. Komunikacja miejska w Lublinie, projekt zmian - Strategia rozwoju trakcji trolejbusowej w Lublinie w latach 2005-2013 [Municipal transport services in Lublin, project of changes. Development strategy of trolley-bus traction in Lublin for 2005-2013]. Lublin: MPK Lublin.

MPK Lublin. 2005. Zintegrowany plan rozwoju transportu publicznego w Lublinie na lata 2005-2013 [Integrated development plan of public transport in Lublin for 2005-2013]. Lublin: MPK Lublin.

Rydzykowski, R.; Wojewódzka-Król, K. 2002. Transport. Warszawa: PWN.

Szadkowski, M. 2000. Komunikacja miejska $w$ Lublinie, projekt zmian - System dworców przesiadkowych [Municipal transport services in Lublin, project of changes - System of transfer stations]. Lublin: MPK Lublin.

Wrzolek, A. 2004. System transportu zbiorowego w Lublinie. Analiza aktualnego stanu, projekt modernizacji [Public transport system in Lublin - Analysis of actual state, project of modernization]. Lublin.

Wyszomirski, O.; Gromadzki, M. 2004. System transportu zbiorowego w Lublinie. Analiza aktualnego stanu. Projekt modernizacji [Public transport system in Lublin. Analysis of actual state, project of modernization]. Gdynia - Lublin. 